J. Great Lakes Res. 26(2):235-239

Internat. Assoc. Great Lakes Res., 2000

\title{
NOTE
}

\section{Age-0 and Age-1 Yellow Perch Diet in Southeastern Lake Michigan}

\author{
Steven A. Pothoven",1, Thomas F. Nalepa ${ }^{2}$, and Stephen B. Brandt ${ }^{2}$ \\ ${ }^{1}$ Cooperative Institute of Limnology and Ecosystem Research, GLERL/University of Michigan \\ Lake Michigan Field Station \\ 1431 Beach Street \\ Muskegon, Michigan 49441 \\ ${ }^{2}$ NOAA-Great Lakes Environmental Research Lab \\ 2205 Commonwealth Boulevard \\ Ann Arbor, Michigan 48105
}

\begin{abstract}
Age-O yellow perch (Perca flavescens) were collected during October 1998 and age-1 yellow perch were collected during June 1999 from southeastern Lake Michigan off St. Joseph and Muskegon, Michigan, to evaluate diets relative to recent ecosystem changes. Size range of yellow perch examined was 72 to $118 \mathrm{~mm}$. In October at a 15-m site off Muskegon, both Gammarus spp. and Isopoda were found in nearly $71 \%$ of age-0 yellow perch stomachs, and accounted for 71 and $26 \%$ of the diet by weight respectively. The following spring at the 15-m site (June 1999), Gammarus spp. and Isopoda were only a small part of age-1 yellow perch diet, and Chironomidae and Mysis relicta dominated the diet. In October at depths of 25 to $35 \mathrm{~m}$. M. relicta, was found in 100 and $80 \%$ of the age-0 yellow perch containing food off Muskegon and St. Joseph, respectively, and comprised over $96 \%$ of the diet by weight. Gammarus spp., Isopoda, and M. relicta were eaten in higher numbers than would be expected based on their low abundance in the environment. The high occurrence of Gammarus spp. and Isopoda in yellow perch diet may indicate ongoing changes in the nearshore benthic community.
\end{abstract}

INDEX WORDS: Yellow perch, fish diets, Lake Michigan.

\section{INTRODUCTION}

The ecology of the nearshore regions of southeast Lake Michigan has undergone widespread changes over the past two decades. Recent changes include possible disruption of the pelagic food web by zebra mussels (Dreissena polymorpha) (Marsden et al. 1993), major declines in the amphipod Diporeia (Nalepa et al. 1998), and invasion by Bythotrephes cederstroemi (Evans 1988). These changes could affect the diet and competitive interactions of fishes in Lake Michigan, including yellow perch (Perca flavescens), which feed on both zooplankton and zoobenthos (Crowder et al. 1981).

Although yellow perch abundance in Lake

*Corresponding author. E-mail: pothoven@glerl.noaa.gov
Michigan has fluctuated widely among years (Wells 1977, Jude and Tesar 1985), a relatively large yearclass occurred in 1998 following nearly 10 years of poor recruitment (D. Jude, Ann Arbor, Michigan, Center for Great Lakes and Aquatic Sciences, University of Michigan, personal communication). The high relative abundance of age- 0 yellow perch provided an opportunity to evaluate diet relative to the environmental changes which have occurred in the southeastern portion of the lake.

\section{METHODS}

Age-0 and age- 1 yellow perch were collected from southeast Lake Michigan as part of a National Oceanic and Atmospheric Administration (NOAA) biological monitoring program. Sampling occurred on 19 October 1998 and 7 June 1999 off Muskegon, 
Michigan, and on 28 October 1998 off St. Joseph, Michigan. Yellow perch were caught during daytime periods using a 7.6-m semi-balloon bottom trawl (13-mm stretch mesh cod-liner). Trawling was conducted along the 15-, 25-, and 35-m bottom depth contours off Muskegon and along the 25- and 35-m contours off St. Joseph. The two sampling areas reflect marked differences in the abundance of Diporeia. Abundances have declined to nearzero off St. Joseph, while abundances are still relatively high off Muskegon (Nalepa et al. 1998). Muskegon is located approximately $120 \mathrm{~km}$ north of St. Joseph.

Fish were immediately frozen upon capture. In the laboratory, fish were measured (total length \pm 1 $\mathrm{mm}$ ), and stomachs were removed. All whole prey organisms were identified and counted; partial prey were counted if they met pre-determined criteria. Prey lengths were measured using a computer image analysis system. Prey length was converted to dry-weight using prey species-specific body length to dry-weight calculations (Johnson and Brinkhurst 1971, Nalepa and Quigley 1980, Smock 1980, Shea and Makarewicz 1989, Makarewicz and Jones 1990, Prejs et al. 1990). Diet is reported as frequency of occurrence (percent of fish containing a given prey type) and percent of the total calculated dry-weight for all fish combined from each sample. Data collected each month as part of the NOAA monitoring program from depths of 15 to 45 $m$ off Muskegon and St. Joseph were used to estimate prey densities. For October 1998, stomach analyses for depths of 25 and $35 \mathrm{~m}$ were combined because only one fish containing food was caught at the 35-m depth off Muskegon, and five fish off St. Joseph. During June 1999, yellow perch were caught only along the 15-m contour off Muskegon.

\section{RESULTS AND DISCUSSION}

Stomach contents from 101 age- 0 yellow perch ranging in length from 72 to $118 \mathrm{~mm}$ (mean $=91$ $\mathrm{mm}$ ) were examined during October 1998. Fourteen age-1 yellow perch ranging in length from 77 to $109 \mathrm{~mm}($ mean $=87 \mathrm{~mm})$ were examined during June 1999. More yellow perch from the 25- to 35depth contours off Muskegon and St. Joseph in October had empty stomachs than from the $15-\mathrm{m}$ contour off Muskegon in October and June (Table 1). Yellow perch with empty stomachs were excluded from further diet analyses. Other fish species collected in trawls included spottail shiners (Notropis hudsonius), alewife (Alosa pseudoharengus), rainbow smelt (Osmerus mordax), slimy sculpin (Cottus cognatus), and bloater (Coregonus hoyi). Mean water column temperatures ranged from $13^{\circ} \mathrm{C}$ during October to $11^{\circ} \mathrm{C}$ during June.

Large macroinvertebrates were the main prey eaten by age-0 yellow perch in October 1998 and by age-1 yellow perch in June 1999. At the $15-\mathrm{m}$ site off Muskegon in October 1998, Gammarus spp.

TABLE 1. Frequency of occurrence (percent) and percent of total dry-weight for diet items found in age0 yellow perch in October 1998 and age-1 yellow perch in June 1999 in southeastern Lake Michigan off Muskegon and St. Joseph, Michigan at 15- and 25-35-m depth intervals. $N=$ total number of fish examined.

\begin{tabular}{|c|c|c|c|c|c|c|c|c|}
\hline \multirow[b]{2}{*}{ Prey } & \multicolumn{2}{|c|}{$\begin{array}{c}\text { October } 1998 \\
\text { Muskegon, } 15 \mathrm{~m}\end{array}$} & \multicolumn{2}{|c|}{$\begin{array}{c}\text { October } 1998 \\
\text { Muskegon, } 25-35 \mathrm{~m}\end{array}$} & \multicolumn{2}{|c|}{$\begin{array}{c}\text { October } 1998 \\
\text { St. Joseph, 25-35 m }\end{array}$} & \multicolumn{2}{|c|}{$\begin{array}{c}\text { June } 1999 \\
\text { Muskegon, } 15 \mathrm{~m}\end{array}$} \\
\hline & Frequency & $\begin{array}{l}\text { Percent } \\
\text { wt. }\end{array}$ & Frequency & $\begin{array}{c}\text { Percent } \\
\text { wt. }\end{array}$ & Frequency & $\begin{array}{c}\text { Percent } \\
\text { wt. }\end{array}$ & Frequency & $\begin{array}{c}\text { Percent } \\
\text { wt. }\end{array}$ \\
\hline Gammarus spp. & 70.6 & 71.0 & 0 & 0 & 0 & 0 & 7.7 & 7.1 \\
\hline Isopoda & 70.6 & 25.8 & 0 & 0 & 0 & 0 & 15.4 & 5.2 \\
\hline Mysis relicta & 5.9 & 0.6 & 100 & 99.3 & 79.5 & 96.2 & 46.2 & 32.0 \\
\hline Bythotrephes cederstroemi & 5.9 & 0.4 & 0 & 0 & 33.3 & 0.8 & 0 & 0 \\
\hline Ostracoda & 0 & 0 & 0 & 0 & 28.2 & 3.0 & 0 & 0 \\
\hline Chironomidae & 23.5 & 1.0 & 11.1 & 0.6 & 0 & 0 & 76.9 & 55.2 \\
\hline Dreissena polymorpha & 17.6 & 0.5 & 0 & 0 & 0 & 0 & 0 & 0 \\
\hline Gastropoda & 11.8 & 0.5 & 0 & 0 & 0 & 0 & 0 & 0 \\
\hline Zooplankton & 0 & 0 & 0 & 0 & 0 & 0 & 38.5 & 0.4 \\
\hline $\mathrm{N}$ & 17 & & 24 & & 60 & & 14 & \\
\hline Percent empty & 0.0 & & 62.5 & & 35.0 & & 7.1 & \\
\hline
\end{tabular}


TABLE 2. Densities (no. $\left./ \mathrm{m}^{2}\right)$ of various prey items in Lake Michigan collected from nearshore (15- to 45-m) sites off Muskegon and St. Joseph, Michigan, during October 1998 and June 1999. Data were collected at 1 to 3 sites during each respective month as part of a NOAA monitoring program (T. Nalepa and S. Pothoven, unpublished data). $N A=$ no prey density data were available.

\begin{tabular}{lccc}
\hline \hline & $\begin{array}{c}\text { October 1998 } \\
\text { Muskegon }\end{array}$ & $\begin{array}{c}\text { October 1998 } \\
\text { St. Joseph }\end{array}$ & $\begin{array}{c}\text { June 1999 } \\
\text { Muskegon }\end{array}$ \\
\hline Gammarus spp. & 0 & 0 & 0 \\
Isopoda & 0 & 0 & 0 \\
Mysis relicta & 47 & NA & 23 \\
Bythotrephes cederstroemi & 39 & NA & 0 \\
Ostracoda & NA & NA & NA \\
Chironomidae & 271 & 7 & 161 \\
Dreissena polymorpha & 1,700 & 0 & 203 \\
Gastropoda & $\mathrm{NA}$ & $\mathrm{NA}$ & 408 \\
Zooplankton & 370,800 & $\mathrm{NA}$ & 270,000 \\
Diporeia & 4,320 & 14 & 2,243 \\
\hline
\end{tabular}

and Isopoda were found in nearly $71 \%$ of the age- 0 yellow perch, and accounted for 71 and $26 \%$, respectively, of the diet by weight (Table 1). The following spring (June 1999) at 15-m off Muskegon, Gammarus spp. and Isopoda were only a small part of the age- 1 yellow perch diet, and Chironomidae and Mysis relicta were mainly eaten. At the 25- to 35-m site in October 1998, age-0 yellow perch fed mainly on $M$. relicta, which occurred in 100 and $80 \%$ of the fish containing food off Muskegon and St. Joseph, respectively, and accounted for almost all of the diet by weight at both sites (> 96\%) (Table 1).

Zooplankton and other benthic prey were a smaller part of the age- 0 and age- 1 yellow perch diet. B. cederstroemi and Ostracoda were found in about a third of the age- 0 yellow perch stomachs off St. Joseph in October, but accounted for a small fraction of the diet by weight (Table 1). B. cederstroemi were eaten mainly by yellow perch larger than $90 \mathrm{~mm}$. Zebra mussels and Gastropoda were eaten by about 18 and $12 \%$, respectively, of the age-0 yellow perch from $15 \mathrm{~m}$ off Muskegon in October, but each comprised $<1 \%$ of the diet by weight (Table 1). Zooplankton were eaten by $38 \%$ of the age- 1 yellow perch at $15 \mathrm{~m}$ off Muskegon in June, but comprised $<1 \%$ of the diet by weight (Table 1).

The dominant prey eaten by age- 0 and age- 1 yellow perch were not the most abundant prey available based on data from nearshore (15 to $45 \mathrm{~m}$ ) monitoring stations off Muskegon and St. Joseph (Table 2). No Gammarus spp. or Isopoda were collected off Muskegon or St. Joseph during fall 1998 or off Muskegon in spring 1999, but they accounted for a large part of the diet (Tables 1 and 2). In contrast, Diporeia, which were still relatively abundant off Muskegon, were not found in any yellow perch stomachs. Gammarus spp. and isopods may be more available to yellow perch than Diporeia because they are found on structures such as rocks or zebra mussels that provide grazing area for predators (Thayer et al. 1997), whereas Diporeia burrow into the bottom sediments (Balcer et al. 1984). A laboratory study reported yellow perch (120 to 130 $\mathrm{mm}$ ) selectively ate Gammarus and isopods in treatments with zebra mussels compared to those without (Thayer et al. 1997).

$M$. relicta densities off Muskegon were low in October and June, but they accounted for much of the diet during both months (Tables 1 and 2). Mysid densities were not available off St. Joseph. Although $M$. relicta is not abundant at depths less than $50 \mathrm{~m}$ (McDonald et al. 1990), their high lipid content makes them a desirable prey for yellow perch when they are available (Gardner et al. 1985). Previous studies have not reported $M$. relicta in age-0 yellow perch diets (Crowder et al. 1981, Baker et al. 1992, Schneeberger 1991). However, age-0 yellow perch were collected from deeper water $(>15$ $m$ depth) where mysids are more abundant and later in the year than these studies. Mysids have been re- 
ported in the diets of older yellow perch than were examined in this study in southeast Lake Michigan (Wells 1980).

The high occurrence of Gammarus spp. and Isopoda in yellow perch diets suggests ongoing changes in the nearshore benthic community are occurring. Neither have been reported as an important prey item for age-0 or older yellow perch in southeastern Lake Michigan throughout the year (Wells 1980, Crowder et al. 1981, Baker et al. 1992). Gammarus spp. densities in spring 1999 at an 18-m site off St. Joseph were $42 / \mathrm{m}^{2}$ (T. Nalepa, unpublished data) and higher compared to historical densities throughout southeast Lake Michigan (Nalepa and Quigley 1980, Winnell 1984, Nalepa 1989). Zebra mussels may be providing habitat for Gammarus spp. and Isopods in areas where they were not previously abundant (Stewart and Haynes 1994, Thayer et al. 1997); in contrast, zebra mussels have been implicated in the decline of Diporeia (Nalepa et al. 1998). Increases in these large benthic prey items would likely benefit age- 0 yellow perch once they are large enough to consume benthic macroinvertebrates (Thayer et al. 1997).

\section{ACKNOWLEDGMENTS}

Assistance in the field was provided by D. Hondorp and the crew of the R/V Laurentian. D. Jude and an anonymous reviewer provided helpful comments. GLERL contribution \# 1159.

\section{REFERENCES}

Baker, E.A., Tolentino, S.A., and McComish, T.S. 1992. Evidence for yellow perch predation on Bythotrephes cederstroemi in southern Lake Michigan. J. Great Lakes Res. 18:190-193.

Balcer, M.D., Korda, N.L., and Dodson, S.I. 1984. Zooplankton of the Great Lakes. A guide to the identification and ecology of the common crustacean species. Madison, Wisconsin: The University of Wisconsin Press.

Crowder, L.B., Magnuson, J.J., and Brandt, S.B. 1981. Complementarity in the use of food and thermal habitat by Lake Michigan fishes. Can. J. Fish. Aquat. Sci. 38:662-668.

Evans, M.S. 1988. Bythotrephes cederstroemi: its new appearance in Lake Michigan. J. Great Lakes Res. 14:234-240.

Gardner, W.S., Nalepa, T.F., Frez, W.A., Cichocki, E.A., and Landrum, P.F. 1985. Seasonal patterns in lipid content of Lake Michigan macroinvertebrates. Can. J. Fish. Aquat. Sci. 42:1827-1832.

Johnson, M.G., and Brinkhurst, R.O. 1971. Production of benthic macroinvertebrates of Bay of Quinte and Lake Ontario. J. Fish. Res. Board Can. 28:1699-1714.

Jude, D.J., and Tesar, F.J. 1985. Recent changes in the inshore forage fish of Lake Michigan. Can. J. Fish. Aquat. Sci. 42:1154-1157.

Makarewicz, J.C., and Jones, H.D. 1990. Occurrence of Bythotrephes cederstroemi in Lake Ontario offshore waters. J. Great Lakes Res. 16:143-147.

Marsden, J.E., Trudeau, N., and Keniry, T. 1993. Zebra mussel study of Lake Michigan. Aquat. Ecol. Tech. Rep. 93/14, Illinois Natural History Survey, Zion, IL.

McDonald, M.E., Crowder, L.B., and Brandt, S.B. 1990. Changes in Mysis and Pontoporeia populations in southeastern Lake Michigan: a response to shifts in the fish community. Limnol. Oceanogr. 35:220-227.

Nalepa, T.F. 1989. Estimates of macroinvertebrate biomass in Lake Michigan. J. Great Lakes Res. 15:437-443.

, and Quigley, M.A. 1980. The macro- and meiobenthos of southeastern Lake Michigan near the mouth of the Grand River, 1976-77. Great Lakes Environmental Research Laboratory, Ann Arbor, MI. NOAA data report ERL GLERL-17.

Hartson, D.J., Fanslow, D.L., Lang, G.A., and Lozano, S.J. 1998. Declines in benthic macroinvertebrate populations in southern Lake Michigan, 1980-1993. Can. J. Fish. Aquat. Sci. 55:2402-2413.

Prejs, A., Lewandowski, K., and StanczykowskaPiotrowska, A. 1990. Size-selective predation by roach (Rutilus rutilus) on zebra mussel (Dreissena polymorpha): field studies. Oecologia 83:378-384.

Schneeberger, P.J. 1991. Seasonal incidences of Bythotrephes cederstroemi in the diet of yellow perch (ages 0-4) in Little Bay De Noc, Lake Michigan, 1988. J. Great Lakes Res. 17:281-285.

Shea, M.A., and Makarewicz, J.C. 1989. Production, biomass, and trophic interaction of Mysis relicta in Lake Ontario. J. Great Lakes Res. 15:223-232.

Smock, L.A. 1980. Relationship between body size and biomass of aquatic insects. Freshwater Biol. 10:375-383.

Stewart, T.W., and Haynes, J.M. 1994. Benthic macroinvertebrate communities of southwestern Lake Ontario following invasion of Dreissena. J. Great Lakes Res. 20:479-493.

Thayer, S.A., Haas, R.C., Douglas Hunter, R., and Kushler, R.H. 1997. Zebra mussel (Dreissena polymorpha) effects on sediment, other zoobenthos, and the diet and growth of adult yellow perch (Perca flavescens) in pond enclosures. Can. J. Fish. Aquat. Sci. 54:1903-1915.

Wells, L. 1977. Changes in yellow perch (Perca flavescens) populations of Lake Michigan. J. Fish. Res. Board Can. 34:1821-1829.

1980. Food of alewives, yellow perch, spottail shiners, trout-perch, and slimy and fourhorn sculpins 
in southeastern Lake Michigan. U.S. Fish. Wildlf. Serv. Tech. Pap. 98.

Winnell, M.H. 1984. Malacostraca (Amphipoda, Mysidacea, Isopoda, and Decapoda). In Ecology of the zoobenthos of Southeastern Lake Michigan near the D. C. Cook nuclear power plant, ed. D.S. White.
Spec. Rep. No. 90 of Great Lakes Res. Div., Univ. Mich, Ann Arbor, MI.

Submitted: 6 April 1999

Accepted: 19 January 2000

Editorial handling: Marlene S. Evans 